\title{
Quality characteristics of paprika packaged with functional film applied by essential oil of Artemisia princeps Pampanini
}

\author{
Miran Jang ${ }^{1 \ddagger}$, Eun-Ji Lee ${ }^{1 \neq}$, Min-Sun Chang ${ }^{2}$, Gun-Hee Kim ${ }^{1 *}$ \\ ${ }^{I}$ Plant Resources Research Institute, DukSung Women's University, Seoul 01369, Korea \\ ${ }^{2}$ Postharvest Technology Division, National Institute of Horticultural and Herbal Science, RDA, Wanju 55365, Korea
}

\section{사자발쑥 정유를 첨가한 기능성 필름의 파프리카 선도 유지 효과}

\author{
장미란 ${ }^{1 \neq} \cdot$ 이은지 ${ }^{1 \neq} \cdot$ 장민선 ${ }^{2} \cdot$ 김건희 $^{1 *}$ \\ ${ }^{1}$ 덕성여자대학교 식물자원연구소, ${ }^{2}$ 국립원예특작과학원 저장유통과
}

\begin{abstract}
The aim of this study was to verify the effect of the essential oil (EO) of Artemisia princeps as a functional film component for enhancing the quality of paprika during storage. EO dilutions of $0.5,1$, and $2 \%$ were used for the experiments, and the bacterial growth inhibition effect of $\mathrm{EO}$ was confirmed against all tested bacteria. The paprika was packaged in $50 \mu \mathrm{m}$-thick polypropylene (PP) film containing $0.5 \% \mathrm{EO}$ and then stored at $10^{\circ} \mathrm{C}$ for 21 days. To determine the effect of EO during paprika storage, the weight loss rate, color, soluble solid content, hardness, microorganism content, appearance, and vitamin $\mathrm{C}$ content were recorded for each sample. It was found that the PP film containing EO $0.5 \%$ prevented water loss, resulting in an improved appearance. In addition, the weight loss rate from the paprika for this film remained unchanged, unlike in the case of the paprika packaged in a comugated box. In addition, the soluble solid contents, hardness, and $\mathrm{CO}_{2}$ contents of the film containing $0.5 \%$ EO were higher than those for the comugated box-stored sample, thereby indicating the positive effect of EO on sample quality maintenance. In terms of the microbial quality assessment, the total number of aerobic bacteria and molds were lower for the $0.5 \%$ EO film-stored sample due to the antimicrobial effect of $A$. princeps. No effect was observed in terms of the vitamin $C$ content. The obtained results therefore suggest that the application of $\mathrm{EO}$ to the PP film is effective for paprika quality preservation.
\end{abstract}

Key words : antimicrobial material, quality, gas composition, packaging, vitamin C

\section{서 론}

파프리카의 원산지는 남아메리카와 중앙아메리카 열 대 지역으로, 영년생 작물이며, 관목상태로 생육한다. 대 과 형의 단 고추로서, 구미에서는 sweet pepper, bell pepper, pimento 등으로 불린다(Choi 등, 2011). 파프리카는 비타민 $\mathrm{A}$ 와 $\mathrm{C}$ 가 풍부하고, $\mathrm{pH}$, 열 및 빛에 안정한 성질을 가지고 있는 알칼리성 식품으로 매운맛이 덜하고 독특한 향이
있다. 또한, 과실의 색깔은 적색, 황색, 오렌지 및 가지색 등으로 다양하고, 일반 피망보다 2-3배 크고 당도가 높아 생식용, 샐러드, 고기 요리의 부재료 등으로 활용도가 높 다(Jung 등, 2004).

파프리카는 비호흡급등형 농산물로써 저장 및 유통되 는 동안에 호흡작용을 통해 과육 내의 수분손실로 인한 외관의 저하와 포장재 내의 곰팡이가 발생하는 등의 품질 저하가 발생하여 수확 후 관리가 중요한 과채류이다. 일반

*Corresponding author. E-mail : ghkim@duksung.ac.kr, Phone : +82-2-901-8496, Fax : +82-901-8661

${ }^{\ddagger}$ These authors contributed equally to this work.

Received 04 February 2020; Revised 29 April 2020; Accepted 06 May 2020.

Copyright (c) The Korean Society of Food Preservation.

This is an Open Access article distributed under the terms of the Creative Commons Attribution Non-Commercial License (http://creativecommons.org/licenses/by-nc/4.0) which permits unrestricted non-commercial use, distribution, and reproduction in any medium, provided the original work is properly cited. 
적으로 과채류의 수확 후 저장에 있어 저온저장이 가장 효과적인 수단으로 이용되고 있으나, 장기 저온저장 시 저온장해와 부패가 발생하는 문제가 있다(Kim 등, 2014). 따라서 이를 대체할 저장법으로 포장재의 기체 투과성을 이용한 modified atmosphere(MA) 저장에 관한 연구가 꾸 준히 진행되고 있다(Lee 등, 2004). 그러나 MA 포장 만으 로는 부패제어에 어려움이 있어, 보다 확실한 수확 후 처 리기술이 필요한 실정이다(Kang 등, 2015). 최근에는 항균 소재를 포함한 포장재를 이용한 MA 포장에 대한 연구가 진행되고 있는데, 안전성 문제를 초래하는 유기화합 항균 물질 대신 천연항균물질을 적용한 연구가 활발히 진행되 고 있다(Lee 등, 2011). 본 연구에 적용된 천연항균물질인 사자발쑥은 약용으로 사용되는 약초로써 항산화 및 항 미생물활성 등 다양한 연구가 이루어져 왔다(Oh 등, 1997; Seo와 Yun, 2011).

따라서 본 연구에서는 사자발쑥 정유의 항균포장재로 의 가능성을 확인하기 위하여 9종의 식중독 및 식품 부패 균주에 대한 항균활성을 측정하였고, 사자발쑥 정유를 첨 가한 기능성 필름을 제조한 후, 이를 파프리카 포장에 적 용하여 저장 중 품질분석을 통해 선도 유지를 위한 최적의 포장재 선발을 하고자 하였다.

\section{재료 및 방법}

\section{실험 재료 및 사자발쑥 정유 추출}

본 실험에 사용된 파프리카는 강원도 홍천시 농가에서
재배하고 2016년 10월에 수확한 것으로, 황색종을 미숙 단계의 초록색상의 상태로 구입하였다. 실험에 사용하기 전의 외관 상태와 모양은 전체적으로 균일한 것을 선별하 여 시료로 사용하였다. 기능성 필름에 사용된 사자발쑥 (Artemisia princeps Pampanini)은 강화 청정지역에서 재배 한 것을 통풍이 잘 되는 그늘에서 3 년간 숙성시키며 말린 것을 구입하였다.

사자발쑥 정유는 사자발쑥 $1 \mathrm{~kg}$ 을 3 차 증류수에 담근 후 clevenger-type apparatus(Hanil Lab Tech Ltd., Incheon, Korea)를 활용하여 9시간 동안 수증기 증류법으로 추출한 것을 사용하였다.

\section{기능성 필름의 제조 및 포장}

포장 필름은 You 등(2015)의 방법을 참고하여 제조하였 다. $50 \mu \mathrm{m}$ polypropylene(PP) 필름을 $20 \times 30 \mathrm{~cm}$ 크기로 절단 한 후, 필름 사이에 polyvinyl alcohol(PVA)과 증류수를 base로 한 필름 제조액에 추출된 사자발쑥 정유를 첨가하 여 제조액 내의 정유 농도가 $0.5 \%$ 가 되도록 하였다. 코팅 기(HSH-1201N, Royal Sovereign, NJ, USA)를 활용하여 접 착한 후, 제조된 기능성 필름은 비닐 접착기(SK-410, Sambo Tech Co., Gimpo, Korea)를 이용하여 필름주머니 형태로 제조하였다. $50 \mu \mathrm{m}$ PP 필름 포장 처리구(일반필름 처리구)와 필름 포장처리를 하지 않은 골판지상자포장 처 리구(무처리구)를 대조군으로 하였으며, $10^{\circ} \mathrm{C}$ 저장고에 저 장하며, 7일 간격으로 품질 특성을 확인하였다.

Table 1. List of strains and cultivation condition used for antibacterial experiment

\begin{tabular}{|c|c|c|c|}
\hline Food-borne pathogens & \multicolumn{2}{|c|}{ Reference } & Cultivation condition \\
\hline Gram positive bacteria & & & \\
\hline Bacillus subtillis & $\mathrm{KCCM}^{1)}$ & 11316 & $\mathrm{NB}^{3)}, 37^{\circ} \mathrm{C}$ \\
\hline Bacillus cereus & $\mathrm{KCCM}$ & 11204 & $\mathrm{NB}, 37^{\circ} \mathrm{C}$ \\
\hline Staphylococcus aureus & $\mathrm{KCCM}$ & 12214 & $\mathrm{NB}, 37^{\circ} \mathrm{C}$ \\
\hline Listeria monocytogenes & $\mathrm{KCCM}$ & 40307 & $\mathrm{NB}, 37^{\circ} \mathrm{C}$ \\
\hline \multicolumn{4}{|l|}{ Gram negative bacteria } \\
\hline Salmonella choleaesuis & $\mathrm{KCCM}$ & 11806 & $\mathrm{NB}, 37^{\circ} \mathrm{C}$ \\
\hline Shigella sonnei & $\mathrm{KCTC}^{2)}$ & 2009 & $\mathrm{NB}, 37^{\circ} \mathrm{C}$ \\
\hline Psedomonas aeruginosa & KCTC & 1636 & $\mathrm{NB}, 37^{\circ} \mathrm{C}$ \\
\hline Aeromonas hydrophila & $\mathrm{KCCM}$ & 2358 & $\mathrm{NB}, 37^{\circ} \mathrm{C}$ \\
\hline Escherichia coli & $\mathrm{KCCM}$ & 12119 & $\mathrm{NB}, 37^{\circ} \mathrm{C}$ \\
\hline
\end{tabular}

${ }^{1)}$ Korean Culture Center of Micro Organisms (Seoul, Korea).

${ }^{2)}$ Korean Collection for Type Culture (Daejeon, Korea).

${ }^{3}$ Nutrient broth. 


\section{사자발쑥 정유의 항균활성 측정}

사자발쑥 정유의 생육저해효과 측정에 사용된 균주는 국내 식중독의 주요 원인 균주들로서 그람양성균 4종, 그 람음성균 5종이었다(Table 1). 본 실험은 Jang 등(2017)의 방법을 적절하게 수정하여 사용하였다. 사용된 균주는 각 $1 \mathrm{~mL}$ 씩 nutrient broth(Difco, Detroit, MI, USA) $9 \mathrm{~mL}$ 에 주입한 후 $37^{\circ} \mathrm{C}$ 에서 24 시간 동안 배양하였고, 총 3 회에 걸쳐 계대배양을 진행한 후 실험에 사용하였다. 배양된 균액은 UV-spectrophotometer(Spectra Max M2, Molecular Decives, $\mathrm{CA}, \mathrm{USA})$ 를 이용하여 $\mathrm{OD}_{600}=0.1-0.2$ 로 농도를 균등하게 조정하여 사용하였다. 96-well plate(Falcon, NJ, USA)에 nutrient broth $98 \mu \mathrm{L}$, 균액 $100 \mu \mathrm{L}$ 및 정유 희석액 $2 \mu \mathrm{L}$ 를 가하여 정유의 최종 농도가 $0.5 \%, 1 \%, 2 \%$ 가 되도록 맞추었다. 이후, 24 시간 동안 $37^{\circ} \mathrm{C}$ 에서 배양하며 4시간마다 UV-spectrophotometer(Spectra Max M2, Molecular Decives) 를 이용해 $600 \mathrm{~nm}$ 에서 흡광도 값을 측정하였다. 생육저 해효과는 식중독균 각각의 생육곡선을 나타내어 추출물 이 균 생장을 저해하는 정도를 확인하였다.

\section{미생물적 품질 특성 평가}

저장기간별 파프리카의 꼭지와 씨를 제거한 과육부분 을 $70 \%$ 에탄올로 소독된 세라믹 칼을 이용하여 $10 \mathrm{~g}$ 을 취하였다. 준비된 파프리카에 $0.85 \%$ 멸균 생리식염수 100 $\mathrm{mL}$ 를 넣고 stomacher(Stomacher Lab Blender, 400, Seward, $\mathrm{NY}, \mathrm{USA}$ )를 이용하여 약 60 초간 균질화하였다. 균질액은 멸균 생리식염수를 사용하여 단계적 희석법에 의해 적절 한 배수로 희석한 후, $1 \mathrm{~mL}$ 를 취하여 일반세균용 aerobic count plates와 곰팡이용 yeast and mold count plates $(3 \mathrm{M}$ Petrifilm Plates, 3M, Maplewood, MN, USA)에 분포하여 $37^{\circ} \mathrm{C}$ 에서 24 시간 동안 배양하였다. 이후, 배양된 집락을 평판계수법으로 측정하였다.

\section{파프리카의 중량감소율 측정}

파프리카의 저장 중 중량감소율은 저장 초기의 중량에 대한 감소량을 백분율로 환산하여 표시하였다. 중량은 시료 의 꼭지 부분을 제거하지 않고 전자저울(CP3202S, Sartorius, Gottingen, Germany)을 이용하여 측정하였다.

\section{파프리카의 색도, 가용성 고형물 함량 및 경도 측정}

저장 중의 파프리카 표면색 변화는 표준백판 $(\mathrm{L}=97.40$, $\mathrm{a}=-0.49, \mathrm{~b}=1.96)$ 으로 보정된 chromameter(CR-400, Konica Minolta Co., Tokyo, Japan)를 이용하여 측정하였으며, 시료 당 부위별 2회씩 5 회 이상 반복 측정하였다.

가용성 고형물 함량의 경우, 과육부분을 blender로 파쇄 한 즙액을 거즈로 여과하여 여과된 액을 디지털 당도계(HI
96801, Hanna Instruments Inc., Woonsocket, RI, USA)를 이 용하여 측정하였다. 한 시료 당 각각 3 회 반복 측정한 후 값을 ${ }^{\circ} \mathrm{Brix}$ 단위로 나타내었다.

경도의 경우, 과육부분을 $2 \mathrm{~cm}$ 의 정사각형 모양으로 자른 후 texture analyser(TAplus 2006, LLOYD Instruments, Bognor Regis, England)에 올린 후, crisp fracture support $\mathrm{rig}$ 를 사용하여 $50 \mathrm{~mm} / \mathrm{min}$, trigger $0.5 \mathrm{~N}$ 조건에서 측정하 였다.

\section{파프리카의 포장재 내 기체조성 측정}

파프리카의 MA 포장재 내의 기체조성을 측정은 gas chromatography(Agilent 6890A GC-NPD, Agilent Technologies, Santa Clara, CA, USA)를 활용하여 산소와 이산 화탄소 함량을 분석하였다. 무처리구, 일반필름처리구 및 사자발쑥 정유 포함 기능성 필름 포장 처리구 모두 $10^{\circ} \mathrm{C}$ 저장고에서 7일 간격으로 포장재 내 가스를 포집하여 기 체조성을 분석하였으며, 분석조건은 Table 2 와 같다.

\section{파프리카의 비타민 C 함량 측정}

파프리카의 비타민 $\mathrm{C}$ 함량 측정을 위하여 꼭지와 씨 부분을 제외한 과피 부분을 신속히 동결건조기(FD5510, Ilshin Lab Co., Ltd., Seoul, Korea)에 넣고 72시간 건조한 후 분말 형태로 분쇄하였다. 동결건조 분말 시료 $1 \mathrm{~g}$ 에 $70 \%$ ethanol을 시료 대비 $1: 50(\mathrm{w} / \mathrm{v})$ 이 되도록 맞춰준 후 120 분간 sonicator(Powersonic 420, 700W, Hwashin Tech, Seoul, Korea)를 사용하여 섞어주었다. 이후, $2,500 \mathrm{rpm}$ 에 서 5 분간 원심분리하였고, 상층액을 $0.45 \mu \mathrm{L} \mathrm{PVDF} \mathrm{syringe}$ filter(Whatman, Maidstone, England)로 여과한 후 HPLC 분 석에 사용하였으며 분석조건은 Table 3 과 같다.

\section{통계처리}

모든 실험 $(\mathrm{n}=3)$ 의, 평균치 간의 유의성은 SPSS system version 19(Statistical Package for Social Sciences, SPSS Inc., Chicago, IL, USA) software package을 이용 하여 $\mathrm{p}<0.05$ 수준으로 Duncan's multiple range test에 의해 검정하였다.

Table 2. GC conditions for analysis of $\mathrm{O}_{2}$ and $\mathrm{CO}_{2}$ gas

\begin{tabular}{cc}
\hline Instrument & Agilent GC \\
\hline Column & $15^{\circ} \times 1 / 8^{\prime \prime}$ stainless steel $(2.1 \mathrm{~mm} \mathrm{ID})$ \\
Oven temperature & $35^{\circ} \mathrm{C}(5 \mathrm{~min})$ to $225^{\circ} \mathrm{C}$ at $20^{\circ} \mathrm{C} / \mathrm{min}$ \\
Carrier gas & Helium, $30 \mathrm{~mL} / \mathrm{min}$ \\
Detector & $\mathrm{TCD}$ \\
Injection volume & $0.6 \mathrm{~mL}$ gas mix \\
\hline
\end{tabular}


Table 3. HPLC conditions for analysis of vitamin C

\begin{tabular}{|c|c|}
\hline Instrument & Agilent HPLC \\
\hline Solvent & $\begin{array}{c}\text { Acetonitrile:50nM NH} \mathrm{NH}_{4} \mathrm{PO}_{4} \\
=70: 30(\mathrm{v} / \mathrm{v})\end{array}$ \\
\hline Flow rate & $1.0 \mathrm{~mL} / \mathrm{min}$ \\
\hline Wavelength & $254 \mathrm{~nm}$ \\
\hline Column & $\begin{array}{l}\text { YMC-Pack Polyamine II } \\
(4.6 \times 250 \mathrm{~mm}, 5 \mu \mathrm{m} \text {, Japan })\end{array}$ \\
\hline Oven temperature & $40^{\circ} \mathrm{C}$ \\
\hline Injection volume & $20 \mu \mathrm{L}$ \\
\hline
\end{tabular}

\section{결과 및 고찰}

\section{사자발쑥 정유의 항균효과}

사자발쑥 정유 추출물이 식중독 및 식품부패균의 생장 에 미치는 영향을 조사하기 위해 최종 농도가 $0.5,1,2 \%$ 가 되도록 정유를 첨가한 후 24 시간 동안 $(0,4,8,20,24$ 시간 $)$ 처리하여 생육 곡선을 나타내었다. 농도별 사자발쑥 정유 의 식중독균에 대한 생육저해효과 결과는 Fig. 1 에 나타내 었다. 사자발쑥 정유 추출물의 농도에 따른 균 생육저해곡 선에서 그람양성균인 S. aureus에 대하여는 모든 농도에서 생육활성이 $50 \%$ 이상 저해되었고, B. subtillis, B. cereus 및 L. monocytogenes의 경우 $1,2 \%$ 의 정유를 첨가하였을 때 균의 생장이 $50 \%$ 이상 저해되어 강한 항균활성이 확인
(A)

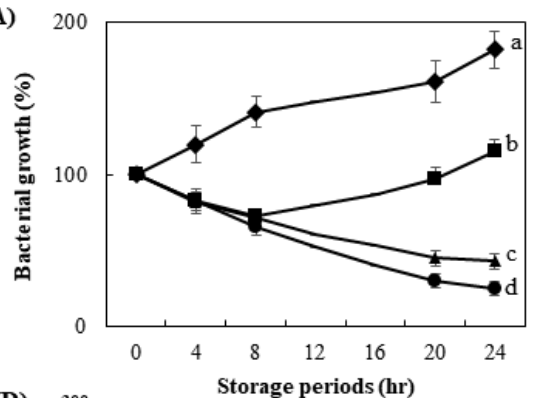

(D)

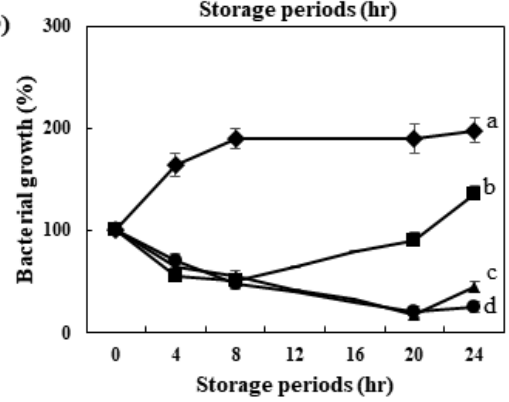

(G)

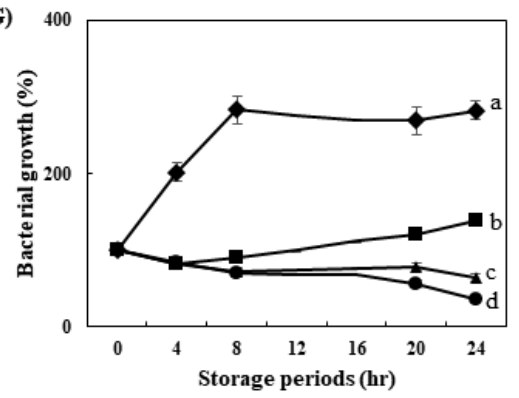

(B)

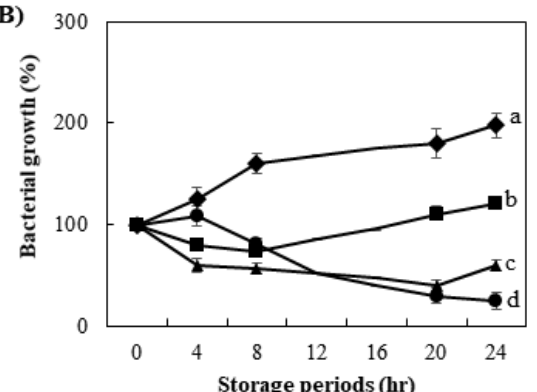

(E)

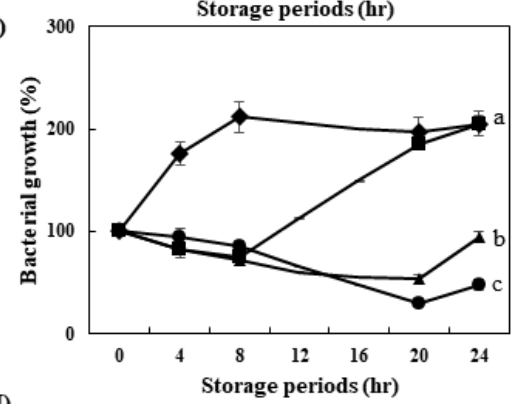

(H)

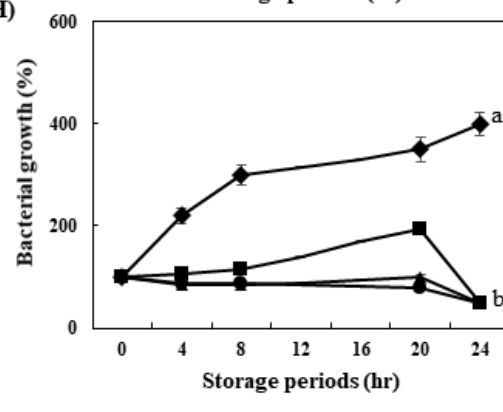

(C)

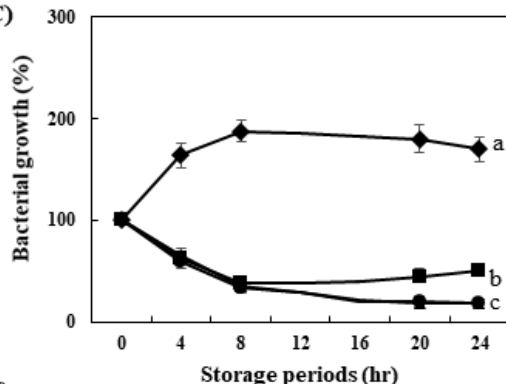

(F)

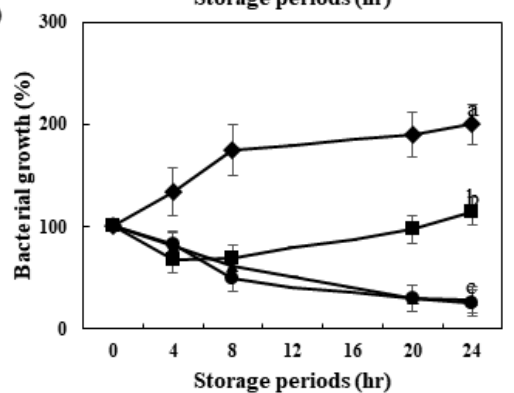

(I)

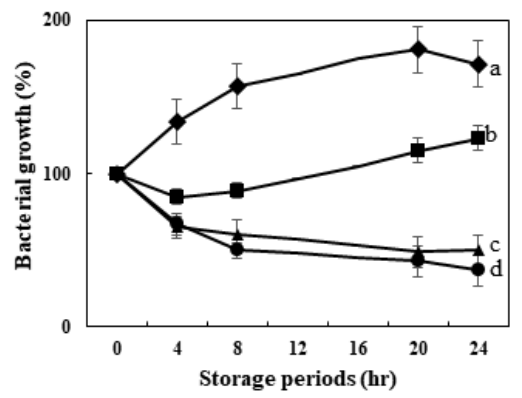

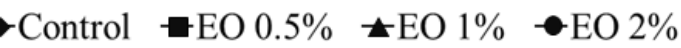

Fig. 1. The inhibition effect of the essential oil of Artemisia princeps Pampanini on the growth of food borne pathogens.

(A), Bacillus subtillis; (B), Bacillus cereus; (C), Staphylococcus aureus; (D), Listeria monocytogenes; (E), Salmonella choleasuis; (F), Aeromonas hydrophila; (G), Psedomonas aeruginosa; (H), Shigella sonnei; (I), Escherichia coli.

EO, essential oil of $A$. princeps.

Each value represented mean \pm SD of three individual experimental results $(n=3)$. Statistical differences in the $24 \mathrm{~h}$ results were distinguished into lowercase letters by Duncan's multiple range test $(p<0.05)$. 
되었다( $\mathrm{p}<0.05)$. 그람음성균의 경우, S. sonnei에 대하여 모 든 농도에서 유의적으로 항균효과가 있음을 확인할 수 있었다 $(\mathrm{p}<0.05)$. 또한, S. choleaesuis와 E. coli에서 저농도 인 $0.5 \%$ 의 경우 배양 8 시간까지 생장이 저해됨이 확인되 었으며, $1,2 \%$ 에 대하여는 두 균 모두 농도에 의존하여 생장이 저해됨을 확인할 수 있었다( $\mathrm{p}<0.05)$. A. hydrophila 와 P. aeruginosa의 경우, $1,2 \%$ 에서 농도 유의적으로 생육 이 저하됨을 확인되었다. 모든 시험균주에 대하여 사자발 쑥 정유 추출물을 첨가하였을 때 농도 유의적으로 생장이 저해되는 것으로 나타났다 $(\mathrm{p}<0.05)$. 이는 쑥 속 식물의 구 강세균에 대하여 효과를 보였던 Woo(2010)의 연구결과 및 일반세균에 대한 항균력을 보였던 Kim 등(2010)의 연 구결과와 일치하였다. 균주의 감수성에 따른 차이는 있으 나, 대부분의 그람음성균 및 그람양성균에서 농도유의적 으로 높은 항균활성을 나타냈다. 정유와 같은 방향성 항균 추출물은 낮은 수용성을 갖기 때문에 식품 산업 적용에 제한적인 것으로 여겨지기도 한다. 그러나, 정유를 식품에 직접 첨가하기보다 간접적으로 향기성분을 확산 및 투여 하거나, 필름으로 개발하여 식품을 포장하여 저장할 경우 새로운 형태의 식품 보존료로의 활용을 기대할 수 있다 (Jang 등, 2010).

\section{파프리카의 미생물적 품질 특성}

사자발쑥 정유 첨가 기능성 필름에 의한 파프리카의 선도 유지 효과를 확인하기 하여 과육 부분의 일반세균 및 곰팡이수를 정 량적으로 조사하여 Table 4에 나타내었 다. 일반세균수는 식품의 생산, 가공 및 유통상의 위생조 건 및 잠재적 식품 부패 등을 판정할 수 있는 지표로 사용 되고 있다(Hong 등, 2013). 무처리구의 일반세균수는 초기 치 $4.35 \pm 1.54 \log \mathrm{CFU} / \mathrm{g}$ 에 비하여 저장 7 일 차에 $5.10 \pm 1.57$ $\log \mathrm{CFU} / \mathrm{g}$ 까지 상승하였다가 이후의 저장기간 동안 감소 하는 경향을 나타냈다. 일반필름 처리구 또한 저장 7 일 차에 $5.16 \pm 1.31 \log \mathrm{CFU} / \mathrm{g}$ 까지 상승하였다가 이후 저장
21 일 차까지 감소하였다. 사자발쑥 정유 첨가 기능성 필름 처리구의 경우, 저장 7 일 차에 상승하고, 21 일 차에 감소하 는 등 무처리구 및 일반필름 처리구와 비슷한 경향을 보였 으며, 저장 14 일까지 사자발쑥 기능성 필름 포장 > 필름포 장 > 무처리구 순서로 일반세균의 증식이 제어되는 것이 확인되었다( $<<0.05)$. 저장 중 파프리카의 곰팡이수 변화는 총 일반세균 수의 변화와 비슷한 양상을 나타내었다. 무처 리구의 곰팡이수 경우 초기치 $2.38 \pm 0.54 \log \mathrm{CFU} / \mathrm{g}$ 에 비하 여 저장 7일 차에 $3.30 \pm 1.09 \log \mathrm{CFU} / \mathrm{g}$ 까지 상승하였다가 저장 21 일 차에 감소하였다. 사자발쑥 기능성 필름 처리구 의 곰팡이 수는 일반 필름에 비해 유의적으로 적게 확인되 었다 $(\mathrm{p}<0.05)$. 골판지포장은 필름포장에 비하여 수분의 손 실이 발생하여 일반세균 및 곰팡이의 생장이 낮게 나타나 는 것으로 사료된다. 하지만 비슷한 수분량을 함유할 수 있는 조건인 일반필름 처리구와 사자발쑥 정유를 포함한 기능성 필름 처리구를 비교하였을 때, 항균성을 지닌 사자 발쑥 정유를 처리한 필름이 일반세균 및 곰팡이 확산을 저해하여 포장재 내의 파프리카의 선도 유지와 부패관리 에 영향을 준 것으로 사료된다.

\section{파프리카의 외관, 중량감소율 및 경도 변화}

과채류의 외관은 상품성 및 선호도를 결정짓는 주요 인자이며, 외관에 영향을 미치는 요인으로는 수분손실에 따른 중량감소율이 있다. 처리구에 따른 저장 기간별 파프 리카의 외관변화는 Fig. 2에 나타냈다. 저장 14일 차에 무 처리구에서 수분 손실로 인한 과육의 우그러짐이 관찰되 었고, 일반필름 처리구와 사자발쑥 정유를 포함한 기능성 필름 처리구에서는 과육의 우그러짐과 같은 이상 외관이 발견되지 않았다. 무처리구의 경우, 저장 14 일 차부터 과 육 내 수분 감소가 급격히 진행되어 과육 품질 저하가 진행되었으며, 저장 21 일 차에는 상품성에 영향을 줄 정도 로 조직감이 완전히 저하되었다. 일반필름 처리구의 경우, 저장 14 일 차까지는 이상 외관이 발견되지 않았으나, 21일

Table 4. Total aerobic bacteria and mold counts of paprika packaged with functional film during storage at $10^{\circ} \mathrm{C}$

\begin{tabular}{|c|c|c|c|c|c|c|}
\hline \multirow{2}{*}{$\begin{array}{l}\text { Storage period } \\
\text { (days) }\end{array}$} & \multicolumn{3}{|c|}{ Total aerobic bacteria counts (log CFU/g) } & \multicolumn{3}{|c|}{ Total mold counts (log CFU/g) } \\
\hline & $\mathrm{CT}^{1)}$ & $\mathrm{PP}$ & EO 0.5 & $\mathrm{CT}$ & PP & EO 0.5 \\
\hline 0 & $4.35 \pm 0.89^{2) \mathrm{NS} 4)}$ & $4.35 \pm 0.89^{\mathrm{NS}}$ & $4.35 \pm 0.89^{\mathrm{NS}}$ & $2.38 \pm 0.32^{\mathrm{NS}}$ & $2.38 \pm 0.32^{\mathrm{NS}}$ & $2.38 \pm 0.32^{\mathrm{NS}}$ \\
\hline 7 & $5.10 \pm 0.91^{\mathrm{a} 3)}$ & $5.16 \pm 0.76^{\mathrm{ab}}$ & $4.86 \pm 0.81^{\mathrm{c}}$ & $3.30 \pm 0.63^{\mathrm{a}}$ & $3.16 \pm 0.87^{\mathrm{ab}}$ & $2.36 \pm 0.32^{\mathrm{c}}$ \\
\hline 14 & $4.59 \pm 1.06^{\mathrm{a}}$ & $4.52 \pm 1.13^{b}$ & $3.95 \pm 0.85^{\mathrm{c}}$ & $3.20 \pm 0.55^{\mathrm{a}}$ & $3.11 \pm 0.64^{\mathrm{ab}}$ & $2.42 \pm 0.20^{\mathrm{c}}$ \\
\hline 21 & $3.09 \pm 1.00^{\mathrm{c}}$ & $3.42 \pm 1.11^{\mathrm{a}}$ & $3.30 \pm 1.09^{\mathrm{b}}$ & $2.56 \pm 0.20^{\mathrm{c}}$ & $3.20 \pm 0.25^{\mathrm{a}}$ & $2.75 \pm 0.10^{\mathrm{b}}$ \\
\hline
\end{tabular}

${ }^{1)} \mathrm{CT}$, corrugated box; PP, polypropylene film $50 \mu \mathrm{m}$; EO 0.5 , essential oil of $A$. princeps $0.5 \%$.

${ }^{2)}$ Each value represented mean \pm standard error of three individual experimental results $(n=3)$.

${ }^{3)}$ Statistical difference within rows of each experiment by Duncan's multiple range test $(p<0.05)$.

${ }^{4)} \mathrm{NS}$, not significantly different at $\mathrm{p}<0.05$. 

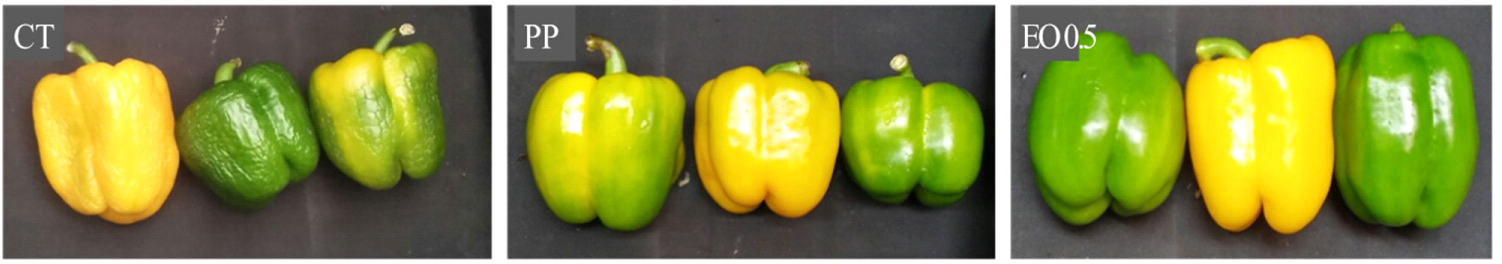

Fig. 2. Changes in appearance of paprika packaged with functional film after 21 days at $10^{\circ} \mathrm{C}$.

CT, corrugated box; PP, polypropylene film $50 \mu \mathrm{m}$; EO 0.5 , functional film with essential oil of A. princeps $0.5 \%$.

차부터 과육의 무름 현상이 관찰되었다. 사자발쑥 정유를 포함한 기능성 필름 처리구의 경우 저장 21 일까지 과피가 우그러지거나 무르게 되는 품질 저하 현상 및 곰팡이의 발생은 관찰되지 않았고, 과육의 신선도가 유지됨을 확인 할 수 있었다.

이와 같이 외관변화에 영향을 주는 주요 요소인 중량감 소에 대한 결과는 Fig. $3 \mathrm{~A}$ 에 나타내었다. 무처리구는 저장 7일 차부터 빠르게 중량감소가 진행되었고, 그 후 저장 21 일까지 꾸준히 중량감소율이 증가하였으며, 다른 처리 구에 비해 유의적으로 높게 나타났다 $(\mathrm{p}<0.05)$. 반면, 일반 필름 처리구 및 사자발쑥 정유를 포함한 기능성 필름 처리 구의 경우 21 일의 저장기간 동안 중량감소가 거의 일어나 지 않았으며, 두 처리구간의 유의적 차이는 없었다 $(\mathrm{p}<0.05)$. 다만, 일반 필름 처리구의 경우 저장 21 일 차가 되었을 때 과육 무름현상이 발견되어 더 이상의 저장 가치 가 없다고 판단되어 21 일에 실험을 종료하였다. 파프리카 는 높은 온도 및 낮은 습도조건에서 식물 조직 내부의 물이 수증기가 되어 기공을 통해 밖으로 나오는 증산작용 이 빠르게 진행되는 과채류로, 이로 인한 수분손실로 중량 이 감소하며, 위조 및 위축으로 모양 및 조직감이 변하고 부피가 감소하므로 파프리카의 품질 저하 요인으로 크게 작용하게 된다(Kim 등, 2010). 일반필름 처리구 및 사자발 쑥 정유를 포함한 기능성 필름 처리구의 경우 필름 포장재 가 수분손실을 막아주고, 이에 따른 포장 내부 증산작용이 더디게 진행되어 낮은 중량감소율 및 외관유지에 효과를 보인 것으로 판단된다.

저장 중 파프리카의 경도 변화는 Fig. 3B에 나타내었으 며, 저장기간이 경과함에 따라 무처리구, 일반필름 및 사 자발쑥 정유를 포함한 기능성 필름 처리구 모두 감소하 는 경향을 나타냈다. 무처리구는 저장 7일 차부터 감소하 였다가 저장 21 일 차까지 포장재를 처리한 처리구에 비 해 유의적으로 급격히 감소하였다. 일반필름 처리구와 사자발쑥 정유를 포함한 기능성 필름 처리구에서는 저장 기간 동안 두 처리구간의 유의적 차이는 나타나지 않았 으나(p<0.05), 두 처리구 모두 지속적으로 감소하는 경향 을 보였다. 파프리카는 아삭하고 단단한 식감과 단맛을 가진 것을 특징으로 하며(Hong 등, 2013) 이러한 식감에
(A)

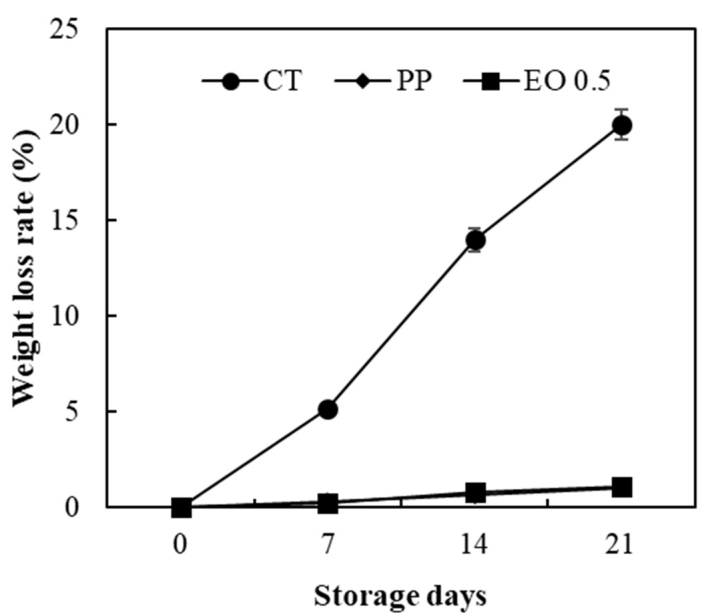

(B)

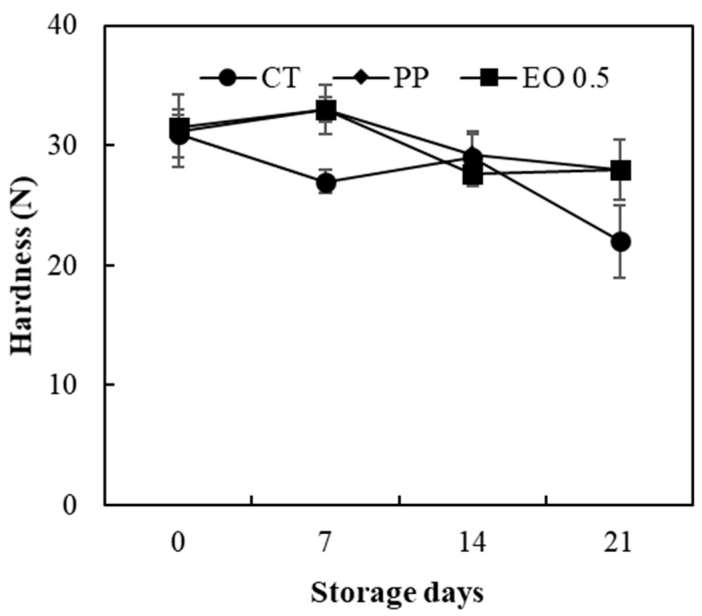

Fig. 3. Changes in (A) weight loss rate and (B) hardness of paprika packaged with functional film during storage at $10^{\circ} \mathrm{C}$.

CT, corrugated box; PP, polypropylene film $50 \mu \mathrm{m}$; EO 0.5 , functional film with essential oil of $A$. princeps $0.5 \%$.

Each value represented mean $\pm \mathrm{SD}$ of three individual experimental results $(n=3)$.

영향을 주는 품질요소인 경도의 감소는 저장기간 동안 수분손실로 인하여 과육의 조직이 위축되고, 조직감이 변하여 발생하는 것으로 식감 및 상품성 저하에도 영향 을 미치게 된다. 따라서 급격히 경도가 감소한 무처리구 
의 경우, 수분손실을 조절하지 못하여 파프리카 경도가 저하된 것으로 생각되며, 일반필름 및 사자발쑥 정유를 포함한 기능성 필름 처리구의 경우 포장재를 통한 과육 내의 수분함량이 유지되어 경도변화에 좋은 영향을 준 것이라 판단된다.

\section{파프리카의 색도 및 가용성 고형물 함량}

파프리카의 저장기간에 따른 표면색은 저장 중 파프리 카의 품질을 결정하는 주요 인자이며, Fig. 4에 나타내었다. 저장기간이 경과함에 따라 모든 처리구에서 $\mathrm{L}, \mathrm{a}$ 및 $\mathrm{b}$ 값 모두 증가하는 경향을 나타냈다. 명도를 나타내는 $\mathrm{L}$ 값의 경우 Fig. $4 \mathrm{~A}$ 와 같이 저장기간 동안 모든 처리구에서 증가 하였으나, 무처리구와 사자발쑥 정 유를 포함한 기능성 필 름 처리구 사이에 유의적인 차이는 확인되지 않았다 $(\mathrm{p}<0.05)$. 그러나 일반필름 처리구의 경우, 다른 처리구와
비교하였을 때 $\mathrm{L}$ 값의 상승이 유의적으로 더디게 진행됨 이 관찰되었다. 적색도를 나타내는 값인 a값의 경우 Fig. $4 \mathrm{~B}$ 와 같이 무처리구에서 비교적 빠르게 상승하여 저장 21 일 차에는 일반필름 및 사자발쑥 정유를 포함한 기능성 필름 처리구에 비하여 높은 $\mathrm{a}$ 값을 나타냈다 $(\mathrm{p}<0.05)$. 일반 필름 처리구와 사자발쑥 정유를 포함한 기능성 필름 처리 구 사이에서는 유의적인 차이가 나타나지 않았다 $(\mathrm{p}<0.05)$. 황색도를 나타내는 b값 또한 무처리구에서 필름처리구에 비하여 높은 값을 나타내었다(Fig. $4 \mathrm{C}$ ). 파프리카의 경우, 숙성이 되는 과정에서 녹색이 황색과 적색으로 변화되는 데, 필름처리구에서 $\mathrm{a}, \mathrm{b}$ 값이 낮게 측정된 것은 필름처리 가 저장 중 파프리카의 급격한 숙성을 억제하는 것으로 사료된다. $\Delta \mathrm{E}$ 값의 경우, Fig. $4 \mathrm{D}$ 와 같이 저장기간 동안 무처리구 및 사자발쑥 정유를 포함한 기능성 필름에 저장 한 파프리카는 지속적으로 상승하였으나 일반필름 처리
(A)

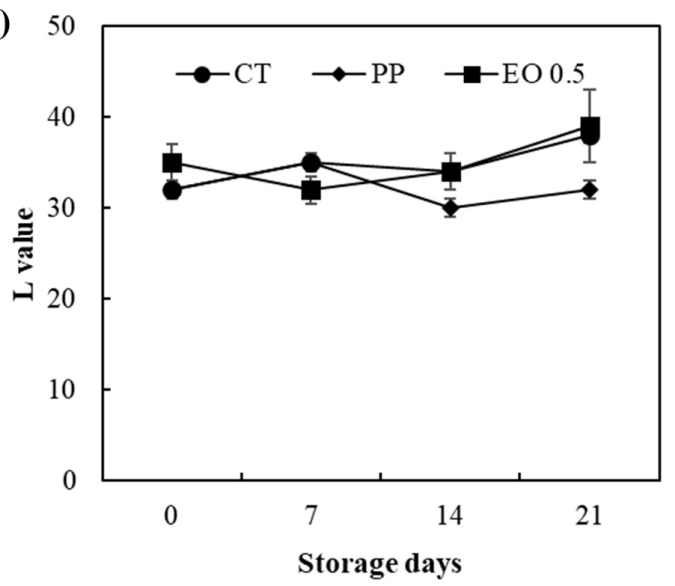

(C)

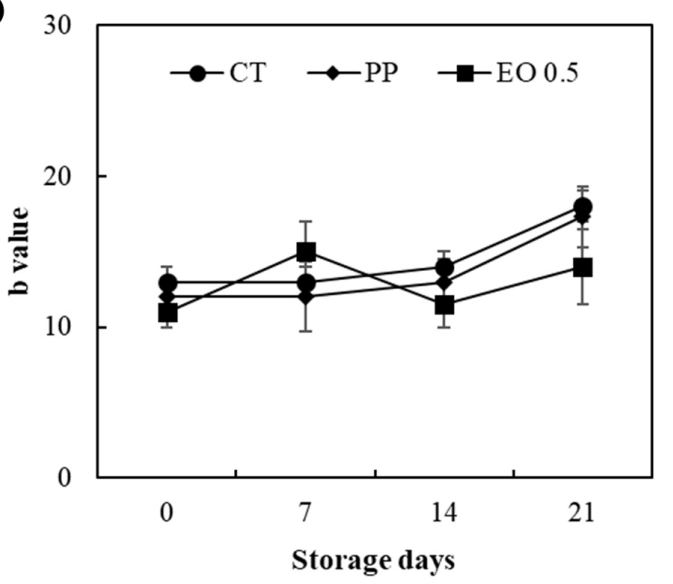

(B)

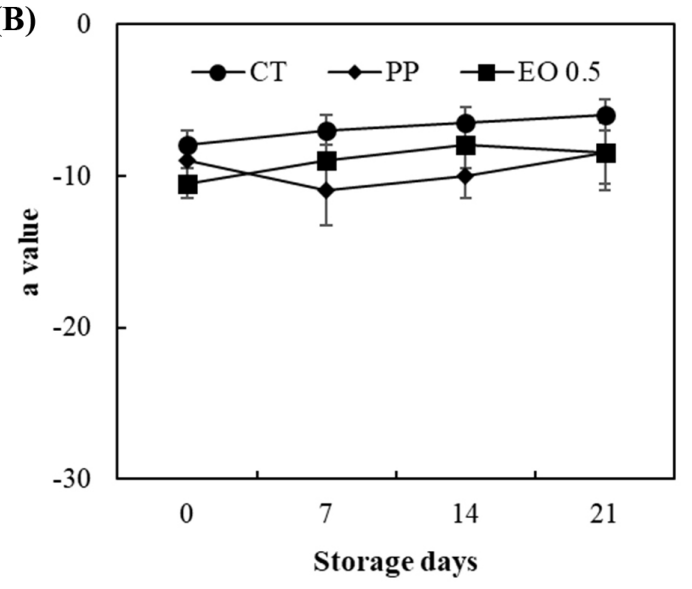

(D)

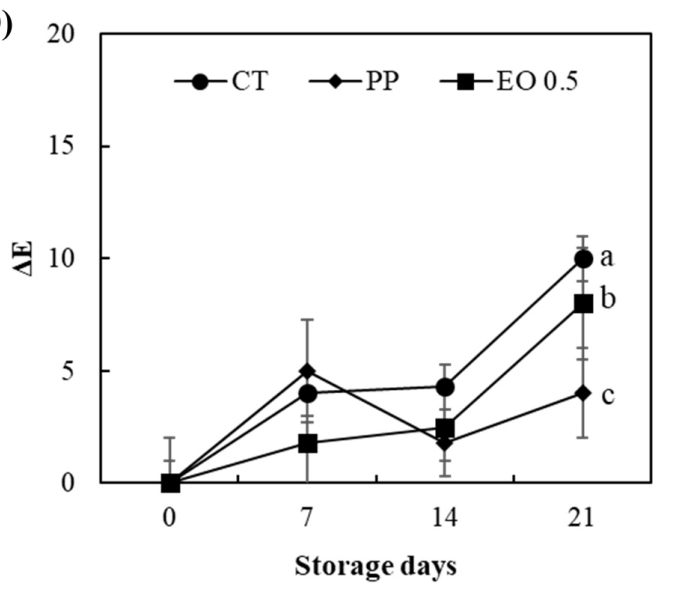

Fig. 4. Changes in Hunter $\mathrm{L}, \mathrm{a}, \mathrm{b}$ value and $\Delta \mathbf{E}$ value of paprika packaged with functional film during storage at $10^{\circ} \mathrm{C}$.

(A), $\mathrm{L}$ value; (B), a value; (C), b value; (D), $\Delta \mathrm{E}$ value.

CT, corrugated box; PP, polypropylene film $50 \mu \mathrm{m}$; EO 0.5, functional film with essential oil of A. princeps $0.5 \%$.

Each value represented mean $\pm S D$ of three individual experimental results $(n=3)$. 
구의 경우 저장 14 일 차에 다소 감소하다 21 일에 다시 상승하는 경향을 보였다. 그러나 일반필름 처리구에서 가 장 낮은 $\Delta \mathrm{E}$ 값을 나타내었다.

가용성 고형물 함량의 경우, 사자발쑥 정유를 포함한 기능성 필름 처리구와 일반필름 처리구에서 저장기간이 경과하면서 소폭 상승했으나, 저장이 진행될수록 감소하 는 경향을 보였다(Fig. 5). 무처리구의 경우, 저장 14 일 차 에 증가하다가 저장 21 일 차에 감소하였으며, 이는 포장재 처리를 한 처리구보다 유의적으로 높게 나타났다 $(\mathrm{p}<0.05)$. 당과 전분을 포함한 후숙 과채류의 품질을 결정짓는 요소 중 하나인 가용성 고형물 함량은 후숙 과정 초기에는 고분 자 물질이 분해되면서 조금씩 증가하다가 분해가 되는 일 정 기간이 지나면 감소한다는 보고가 있는 반면(Yun 등, 2008), 저장일수가 길어지면서 과육의 수분함량 감소에 따라 증가한다는 보고도 있다(Park 등, 2002). 또한, 후숙 과정에서 호흡작용으로 인해 저장된 당이 소모되고, 과실 내 전분이 당으로 가수분해되어 건물 함량 감소와 함께 가용성 고형물 함량이 증가한다는 보고도 있다 $(\mathrm{Lim}$ 등, 2017; Yoon과 Kang, 2017), 따라서 본 연구에서는 저장 중 의 다양한 요인이 복합적으로 작용하여 가용성 고형물의 함량에 영향을 미쳤을 것으로 판단된다.

\section{파프리카의 포장재 내 기체조성 측정}

신선식품의 저장 및 포장에 있어 산소 및 이산화탄소의 농도는 포장 식품의 품질을 결정하는 주요 인자로 여겨진 다. 본 연구에서 파프리카의 포장재 내부 이산화탄소 및 산소농도를 측정한 결과는 Fig. 6과 같다. 무처리구는 저 장기간 동안 일반대기 조성과 같이 약 $21 \%$ 의 산소농도를

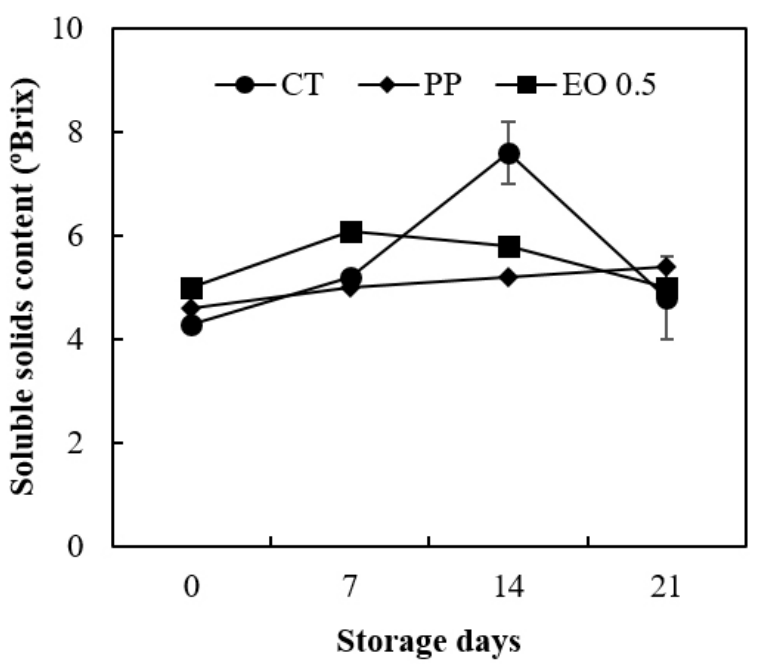

Fig. 5. Changes in soluble solids content of paprika packaged with functional film during storage at $10^{\circ} \mathrm{C}$.

CT, corrugated box; PP 50, polypropylene film $50 \mu \mathrm{m}$; EO 0.5 , functional film with essential oil of $A$. princeps $0.5 \%$.

Each value represented mean $\pm \mathrm{SD}$ of three individual experimental results $(n=3)$.

유지하였다. 반면, 일반필름 및 사자발쑥 정유를 포함한 기능성 필름 처리구는 모두 7일 차에 급격하게 감소하여 21 일 차까지 유지되었다. 이산화탄소의 경우, 무처리구에 서 저장기간 동안 일반대기 조성과 같은 이산화탄소 농 도, 약 $0.3 \%$ 를 유지하였다. 일반필름 및 사자발쑥 정유를 포함한 기능성 필름 처리구에서는 저장 7일 차에 이산화 탄소의 양이 급격하게 증가했다가 21일 차까지 유지되었
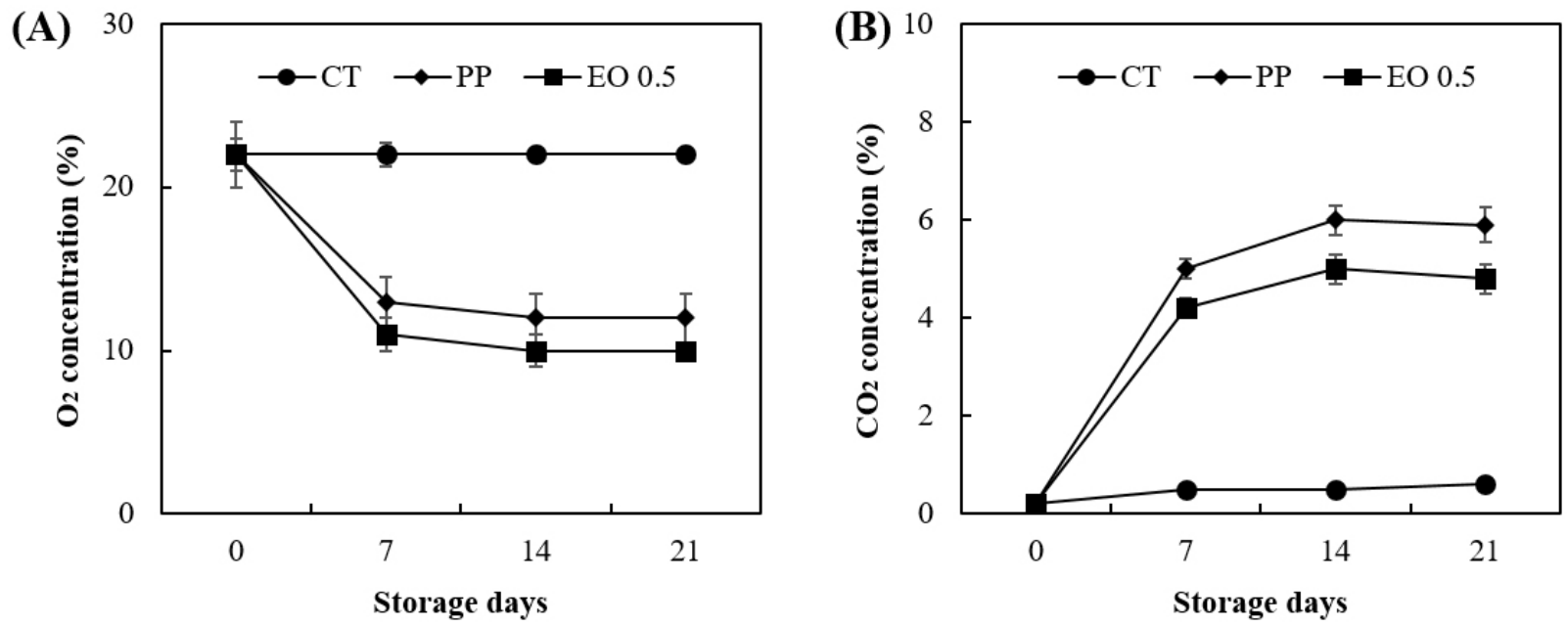

Fig. 6. Changes in $\mathrm{O}_{2}$ and $\mathrm{CO}_{2}$ concentration of paprika packaged with functional film during storage at $10^{\circ} \mathrm{C}$.

(A), $\mathrm{O}_{2}$ concentration; (B), $\mathrm{CO}_{2}$ concentration.

CT, corrugated box; PP, polypropylene film $50 \mu \mathrm{m}$; EO 0.5 , functional film with essential oil of A. princeps $0.5 \%$. Each value represented mean $\pm \mathrm{SD}$ of three individual experimental results $(\mathrm{n}=3)$. 
다. 포장 내부의 식품의 호흡으로 인하여 산소 고갈 및 이산화탄소 축적은 신선 농산물의 혐기호흡을 유발하여 외관의 부정적 변화와 이취를 발생시켜 신선식품의 상품 성을 떨어뜨릴 수 있다(lee 등, 2013). 한편, 산소와 이산화 탄소 등의 기체 조성은 포장 필름의 종류와 저장 식품의 호흡량에 따라 포장 내부의 농도가 다르게 형성된다. 본 연구에서 사자발쑥 정유를 포함한 기능성 필름으로 파프 리카를 포장하였을 때 이산화탄소가 약 $5 \%$ 까지 상승하 였는데, 파프리카의 경우 저장고 내의 이산화탄소 농도가 $5 \%$ 로 유지되는 기체환경은 파프리카의 신선도 유지에 도움을 준다는 연구결과(Lee 등, 2015)와 비교해 보았을 때 저장기간 동안 포장재내의 이산화탄소가 $5 \%$ 내외로 유지되었던 사자발쑥 정유를 포함한 기능성 필름 처리구 에서 파프리카 신선도 유지를 위한 최적의 이산화탄소 농도를 유지하여 선도 유지에 도움이 되었음을 확인할 수 있었다.

\section{파프리카의 비타민 C 함량}

저장기간별 파프리카의 비타민 C 함량은 Table 5 와 같 다. 무처리구의 경우, 초기치 $350.03 \pm 3.44 \mu \mathrm{g} / \mathrm{mL}$ 대비, 저 장 7일 차에 $264.30 \pm 50.10 \mu \mathrm{g} / \mathrm{mL}$ 로 감소하였으나, 이후에 다시 증가하는 경향을 보였다. 일반필름 처리구의 경우, 저장 7일 차에 $293.20 \pm 87.51 \mu \mathrm{g} / \mathrm{mL}$ 로 감소하였다가 저장 14 일 차까지 유지되었으나 유의적 차이는 보이지 않았고, 저장 21 일 차에는 $329.47 \pm 20.48 \mu \mathrm{g} / \mathrm{mL}$ 로 증가하였다. 사 자발쑥 정유를 포함한 기능성 필름 처리구의 경우 저장 7일 차에 $259.65 \pm 50.04 \mu \mathrm{g} / \mathrm{mL}$ 로 감소 후 저장 14 일 차에 $352.66 \pm 123.30 \mu \mathrm{g} / \mathrm{mL}$ 로 증가하였으나, 이후 그 양이 감소 하였다. 무처리구의 경우, 저장 21 일 동안 필름을 처리한 처리구와 비교하였을 때 전반적으로 높은 비타민 $\mathrm{C}$ 함량

Table 5. Effect of various packacges on vitamin $\mathrm{C}$ content of fresh paprika during storage at $10^{\circ} \mathrm{C}$

\begin{tabular}{cccc}
\hline \multirow{2}{*}{$\begin{array}{c}\text { Storage } \\
\text { period } \\
\text { (days) }\end{array}$} & \multicolumn{3}{c}{ Vitamin C contents $(\mu \mathrm{g} / \mathrm{mL})$} \\
\cline { 2 - 4 } & $\mathrm{CT}^{1)}$ & PP & EO 0.5 \\
\hline 0 & $350.03 \pm 1.99^{2) \mathrm{NS} 4)}$ & $350.03 \pm 1.99^{\mathrm{NS}}$ & $350.03 \pm 1.99^{\mathrm{NS}}$ \\
7 & $\left.264.30 \pm 28.93^{\mathrm{b} 3}\right)$ & $293.20 \pm 50.52^{\mathrm{a}}$ & $259.65 \pm 28.89^{\mathrm{b}}$ \\
14 & $332.95 \pm 28.74^{\mathrm{ab}}$ & $292.81 \pm 24.60^{\mathrm{b}}$ & $352.66 \pm 71.19^{\mathrm{a}}$ \\
21 & $415.35 \pm 38.01^{\mathrm{a}}$ & $329.47 \pm 11.82^{\mathrm{b}}$ & $320.56 \pm 20.42^{\mathrm{b}}$ \\
\hline
\end{tabular}

${ }^{1)} \mathrm{CT}$, corrugated box; PP 50, polypropylene film $50 \mu \mathrm{m}$; EO 0.5 , essential Oil of $A$. princeps $0.5 \%$.

${ }^{2)}$ Each value represented mean \pm standard error of three individual experimental results $(\mathrm{n}=3)$.

${ }^{3}$ Statistical difference within rows of each experiment by Duncan's multiple range test $(\mathrm{p}<0.05)$.

${ }^{4} \mathrm{NS}$, not significantly different at $\mathrm{p}<0.05$.
을 유지하였고, 일반필름 처리구와 사자발쑥 정유를 포함 한 기능성 필름 처리구의 경우 저장 7 일 및 14 일을 제외하 고 유의적 차이를 보이지 않았다 $(\mathrm{p}<0.05)$. 비타민 $\mathrm{C}$ 의 함량 은 신선도와 밀접한 관계가 있어 저장일수가 증가할수록 지속적인 감소가 나타날 것으로 생각되었으나, 14 일 이후 에는 파프리카의 수분함량 감소로 인하여 중량대비 비타 민 $\mathrm{C}$ 함량이 상대적으로 높게 측정되는 것으로 사료된다.

본 연구 결과, 사자발쑥 정유의 항균활성을 기반으로 천연 항균 사자발쑥 정유를 함유한 기능성 필름은 파프리 카의 저장 중 부패 방지 및 신선도 유지에 효과가 있어 기능성필름으로써 활용될 수 있는 가능성을 확인하였다. 사자발쑥 정유 필름을 산업화에 적용하기 위하여 신선식 품을 저장하는 동안 증식하는 균의 생육을 저해하는 시간 과 농도에 대한 연구가 필요하며, 또한 파프리카에 쉽게 증식하는 부패균주에 대한 항균실험이 후속 연구로 필요 할 것으로 사료된다.

\section{요 약}

본 연구에서는 천연 항균 추출물 사자발쑥 정유를 활용 하여 기능성필름을 제조한 후, 파프리카의 저장 중 품질유 지 및 부패 제어를 위한 연구를 진행하였다. 기능성필름 포장재의 파프리카에 대한 효과를 확인하기위해 모든 시 료를 $10^{\circ} \mathrm{C}$ 저장고에서 저장하며 품질평가를 진행하였다. 일반필름 처리구 및 사자발쑥 정유를 포함한 기능성필름 처리구의 경우, 필름 포장재가 수분손실을 막아주고, 이에 따른 포장 내부 증산작용이 더디게 진행되어 더 나은 외관 유지를 할 수 있었으며, 무처리구에 비하여 낮은 중량감소 율, 높은 고형물 함량 보유, 높은 경도를 유지할 수 있었다. 또한, 저장기간 동안의 기체조성의 경우 사자발쑥 정유를 포함한 기능성 필름 처리구에서 높은 이산화탄소 함량을 유지하여 품질유지에 긍정적인 영향을 주었다. 미생물적 품질평가에서도 사자발쑥의 항균효과에 의하여 총 일반 세균 수와 곰팡이 수가 낮게 관찰되었다. 비타민 $\mathrm{C}$ 함량의 경우 무처리구에서 높게 유지되었으나, 저장시 처리에 의 한 차이보다도 수분함량에 의한 영향인 것으로 사료되어 추가적인 실험이 요구된다. 본 연구 결과를 종합해보면, 천연 항균물질인 사자발쑥 정유를 함유한 기능성필름은 파프리카의 저장 중 신선도 유지 및 부패 방지에 긍정적인 효과를 나타내는 것이 확인되어 기능성필름으로써 활용 될 수 있는 가능성을 확인하였다.

\section{감사의 글}

본 연구는 농촌진흥청 공동연구사업의 지원(PJ010236 012016)에 의해 수행되었음. 


\section{Conflict of interests}

The authors declare no potential conflict of interest.

\section{ORCID}

Miran Jang https://orcid.org/0000-0001-5934-982X

Eun-Ji Lee https://orcid.org/0000-0002-3861-6324

Gun-Hee Kim https://orcid.org/0000-0001-8196-7149

\section{References}

Choi JW, Kim SY, Lee WM, Kim WB, Rhee HC, Hong YP. Effect of chlorine dioxide treatment on postharvest quality of paprika. Korean J Hort Sci Technol, 129, 92-93 (2011)

Hong HJ, Kim AJ, Park HR, Shin JK. Changes in physicochemical properties of paprika by intense pulsed light treatment. Korean J Food Sci Technol, 45, 339-344 (2013)

Jang M, Hong E, Kim GH. Evaluation of antibacterial activity of 3-butenyl, 4-pentenyl, 2-phenylethyl, and benzyl isothiocyanate in Brassica vegetables. J Food Sci, 75, M412-M416 (2010)

Jang M, Kim GH. Inhibitory effect of novel thioflavone derivatives against foodborne and spoilage microbes on fresh fruit. J Food Safety, 37, e12337 (2017)

Jung JY, Choi MH, Hwang JH, Chung HJ. Quality characteristics of Jeung-Pyun prepared with paprika Juice. Korean J Food Soc Food Sci Nutr, 33, 869-874 (2004)

Kang JH, Park SM, Kim HG, Son HJ, Song KJ, Cho MA, Kin JR, Lee JY, Song KB. Gaseous chlorine dioxide treatment to produce high quality paprika for export. J Korean Soc Food Sci Nutr, 44, 1072-1078 (2015)

Kim HE, Hwang MR, Eom JH, Choi HG, Kang NJ. Effects of methyl jasmonate on shelf life of paprika. J Agric Life Sci, 48, 19-25 (2014)

Kim JS, Choi HR, Chung DS, Lee YS. Current research status of postharvest and packaging technology of oriental melon (Cucumis melo var. makuwa) in Korea. Kor J Hort Sci Technol, 28, 902-911 (2010)

Lee HH, Hong SI, Kim DM. Storage quality of sulhyang strawberries as affected by high $\mathrm{O}_{2}$ atmosphere packaging. Korean J Food Sci Technol, 45, 191-198 (2013)

Lee SH, Lee MS, Lee YW, Yeom HJ, Sun NK, Song KB.
Effect of packaging material and storage temperature on the quality of tomato and plum fruits. Korean J Food Preserv, 11, 135-141 (2004)

Lee SY, Lee SJ, Choi DS, Hur SJ. Current topics in active and intelligent food packaging for preservation of fresh foods. J Sci Food Agric, 95, 2799-2810 (2015)

Lee YS, Lee YE, Lee JS, Kim YS. Effect of antimicrobial microperforated film packaging on extending shelf life of cluster-type tomato (Lycopersicon esculentum Mill.). Korean J Hort Sci Technol, 29, 447-455 (2011)

Lim YJ, Lim CK, Eom SH. Changes in bioactive components, antioxidant radical scavenging activities, and cholinesterase inhibition activities in periodically harvested and post-harvested kiwifruits. Hort Sci Technol, 36, 245-255 (2018)

Oh TY, Ahn BO, Ko JI, Ryu BK, Son MW, Kim SH, Kim WB, Lee EB. Studies on protective effect of DA-9601, an Artemisia herbal extract, against ethanol-induced gastric mucosal damage and its mechanism. J Appl Pharmacol, 5, 202-210 (1997)

Park WP, Cho SH, Kim CH. Changes in quality characteristics of cherry tomato packaged with different films. Korean J Food Preserv, 9, 121-125 (2002)

Seo KS, Yun KW. Antimicrobial activity and total polyphenol content of extracts from Artemisia capillaris Thunb. and Artemisia iwayomogi Kitam. used as Injin. Korean J Plant Res, 24, 10-16 (2011)

Woo JH. Antioxidant and antimicrobial activities from functional components of major commercial herb essential oil products in Korea and foreign countries, Korea. Korean J Hort Sci, 28, 38-39 (2010)

Yoon HS, Kang HM. Influence of pretreatments and modified atmosphere packaging on toughness and quality of asparagus spears during storage. Hort Sci Technol, 35, 717726 (2017)

You HR, Chang MS, Kim GH. Quality characteristics of tomato packaged with functional film applied to essential oil of Artemisia princeps Pampanini. J Korean Soc Food Cult, 30, 766-772 (2015)

Yun HJ, Lim SY, Hur JM, Lee BY, Choi YJ, Kwon JH, Kim D. Changes of nutritional compounds and texture characteristics of peaches (Prunus persica L. Batsch) during post-irradiation storage at different temperature. Korean J Food Preserv, 15, 377-384 (2008) 